\title{
Family Secrets: Law and Understandings of Openness in Everyday Relationships
}

\author{
CAROL SMART \\ Co-Director, The Morgan Centre for the Study of Relationships and Personal Life, School of \\ Social Sciences, University of Manchester, Arthur Lewis Building, Oxford Road, Manchester \\ M13 9PL \\ email: carol.smart@manchester.ac.uk
}

\begin{abstract}
Uncovering old or historical family secrets has become an enjoyable pastime yet in contemporary families the keeping of secrets, especially those relating to reproduction and paternity, is seen increasingly as undesirable. This article explores these issues and the growing tendency for family law and policy to favour exposing genetic truths - seeing this form of scientific veracity as crucial to child welfare and equality. The article explores the changing contexts of family secrets (using data drawn from the Mass Observation Archive) and seeks to locate these secrets in their cultural and historical context. An argument against imposing a simple solution (in the form of genetic truth) onto complex relationships is pursued.
\end{abstract}

\section{Introduction}

Uncovering family secrets has become a popular pastime. Not only do stories of revealed family secrets make good newspaper copy, ${ }^{1}$ but genealogical searches are often tinged with the prospective excitement of finding a family secret buried in the past. ${ }^{2}$ Stories of illegitimacy, bigamy and even criminality seem to become charming, as long as they occurred sufficiently long ago. Part of the pleasure in uncovering secrets is perhaps the way in which the discovery gives the lie to the idea of an idyllic past, when families were all supposed to be respectable, Godfearing and law-abiding. It may also be that recognising human frailty in the past helps us to be more understanding of contemporary failings and mistakes. Of course, not all old secrets are charming, and some retain their ability to scandalise or haunt in distressing ways ${ }^{3}$ so it would be unwise to assume that searching for secrets is always a harmless exercise. But it would seem that, notwithstanding the risks, the search for old secrets has become compelling and the availability, in the UK, of Census and other historical data on-line seems to have fuelled the enthusiasm for this new pastime.

This fascination for old secrets is itself interesting because while the content of secrets (and the nature of things deemed shameful or unknowable) may change as social conditions change (Davidoff et al., 1999; Goudsblom and Mennell, 1998), it seems that the desire to uncover past secrets is also subject to fluctuations and 
change. There seems, in the UK at least, to be an urgency around revealing or exposing personal truths which was not so prevalent 50 or more years ago. But the general trend towards speaking the truth and finding authenticity through truth has a longer, more gradual history. It will be necessary to outline what I mean by this and I shall then turn to issues arising from the substance of certain family secrets and give consideration to the desire for openness in personal relationships which is gaining ground in both legal and family policy.

\section{The will to truth}

Michel Foucault (1979) wrote extensively on what he termed the will to truth as part of his analysis of the rise of scientific knowledge. His concern was not with the question of what was actually 'true' and what was not, but with the way in which claims to truth became seen as the most authentic mode of knowledge creation. Ultimately, in his account, claims to scientific truth could assert greater authenticity than other forms of knowledge such as belief, faith or religion. Thus a claim to truth was for him also a way of exercising power since power and knowledge were but two sides of the same coin. In the field of personal life, Foucault identified the rise of the 'psy' sciences and professions (psychoanalysis, psychiatry and psychology and so on) as crucial in the process of developing supposedly fundamental knowledge about the self. These new sciences also developed different methodologies for excavating the (supposedly) authentic truth of the person. One particular method he focused on was, of course, the talking cure (psychoanalysis) through which the individual was induced to tell everything about him/herself to the therapist in order to expose the 'true' self hidden in the unconscious. For Foucault this talking cure was the Catholic confession revamped in a scientific form, and he saw it as part of the modern governance of the self (both by the professions and by the individual) (Rose, 1991). This method, which became popularised throughout the twentieth century (for example, through counselling and relationship manuals, viz Furedi, 2004; Giddens, 1992; Hazleden, 2004), came to insist that the healthy self and the healthy relationship require truth telling and also deep and intimate revelations about one's most authentic, but most hidden, core. Importantly, in Foucault's analysis, much of what was deemed to be 'core' concerned matters of sexuality and so, at this microlevel, truth telling was focused intensively on sexual behaviour and desires.

Truth therefore, I suggest, has come to occupy a special place in personal life, or at least in how it is believed that personal life should be lived. It is perceived as the source of healing (of the self) and, normatively speaking, the only acceptable basis for 'proper' personal relationships. Hence, deceiving oneself is seen as leading to neuroses of various sorts, while deceiving those with whom one has a close relationship is seen automatically to jeopardise the quality of the bond and to undermine genuine feelings. Moreover, confiding intimacy has been elevated to being the core element in modern 'pure relationships' (Giddens, 1992) and the 
the defining feature of democratic intimacy (Jamieson, 1998, 1999). In this broad context it becomes increasingly difficult to imagine, let alone support, the idea of keeping secrets in families and in relationships. Axiomatically such behaviour is deemed to be at best selfishly retentive and at worst harmful. It has perhaps become seen as so detrimental that law may be increasingly called upon to help uncover personal secrets and to expose them to scrutiny. For example, in recent decades English family law has become wedded to the idea of encouraging truth in matters to do with reproduction, parenthood and, most particularly although not exclusively, with paternity. The apparently inexorable rise of commercial paternity testing promoted as giving men 'peace of mind' and the increasing resort to ordering DNA tests in cases of disputed paternity are indicators of the ways in which legal truth is being increasingly forced into line with (what John Eekelaar, 2006, has called) 'physical' truth. In the realms of adoption and now assisted reproduction, it is increasingly frowned upon and actively discouraged for a parent or parents to mislead their children about their genetic inheritance. The days in which a genetic parent could be 'erased' or de-kinned (Konrad, 2005) appear to be vanishing, not least because the modern child's ontological security is understood to rest on knowing the truth of their conception (Carsten, 2000; Smith and Logan, 2004). I stress the modern child because until roughly the 1960 , in the case of adoption, and the 1980s, in the case of assisted reproduction, ontological security was seen as resting in an 'untruth'. Thus the child's belief that his or her social parent(s) was also his/her biological parent(s) was seen as entirely appropriate. What has happened over the last half century in the UK has therefore been a struggle over the place of truth in family relationships.

Eekelaar (2006) has mounted an extremely compelling argument for the total alignment of legal and 'physical' truth. Only this way, he argues, can the shame of illegitimacy, adoption or infertility be overcome. His argument is based on two foundations. First, providing a modern day exemplar of Foucault's argument, he insists that proclamations of 'real' truth can sweep away outmoded and restrictive (harmful) beliefs. A combined legally enforced genetic truth is seen as a powerful way to eradicate superstition and bigotry because it has a greater claim to authenticity. Second, and most compellingly, he argues that the keeping of secrets about paternity and parenthood denies truth to the next generation and thus disenfranchises them from any claim to justice. Thus he argues that the older generation (for example, parents) keep reproductive or sexual secrets in order to protect their own powerful interests. In so doing he suggests parents deny their children the right to know or to have information which they could decide to use according to their own needs. He argues:

Adults can create legal truths which are at odds with physical truth. They may deliberately disguise physical truths. When they do that, you can be sure that it is in order to project the social order constructed by the adults into the future. ... So this knowledge [of physical truth] allows the individual to confront the world as it is on his own terms, and influence solutions according to his perception of his interests given the physical truth. But with physical truth 
forever obscured, society's new members are doomed to manipulation. (Eekelaar, 2006: 74, emphasis in original)

Eekelaar's argument is forceful, drawing as it does on the image of the innocent and vulnerable child at the mercy of self-interested adults who seek to preserve their social order and perpetuate it into the future. He sees the struggle over reproductive truth as a manifestation of generational power through which elders seek to control and manipulate the next generation. Unlike others who resort to the concept of the best interests of the child as the motive for insisting on reproductive truth (for example, Fortin, 1994), Eekelaar relies on claims to justice which children are deprived of if they are denied the truth of their genetic inception. So Eekelaar does not embroil himself in the problems of shifting normative values around child welfare, but rather resorts to a more universal claim to justice for each new generation based on the alignment of legal and 'physical' truth.

Given the strength of Eekelaar's claims it might seem misguided to argue against him because to do so would seem to reject enlightened thinking while simultaneously mounting a case in favour of lies, deceit and the manipulation of children. Yet there could be several problems with this proclamation in favour of (one) truth at any cost. In what follows I shall explore the complex area of family secrets. In so doing I wish to give a context to these secrets and to explore potential links between different kinds of reproductive secrets as they have changed their form over time. I want to question the idea that there is a simple 'physical' truth, for although there may now be some specific genetic truths that can be established, there are also other truths which may be just as important in family life. We need to consider how this one form of truth (genetic parentage) has become so overarching in significance. We also need to give consideration to how real people live with truths and untruths (or complexities of truths) and whether, in these matters, power is something that only flows down the generations. I shall argue that gendered power relations remain important, and that social and cultural context can also render simple claims to one easily understood truth more complicated than Eekelaar allows.

\section{Kinship, relationships and the significance of genes}

Sociological and anthropological approaches to understanding relationships now referred to in anthropology as the new kinship studies (Carsten, 2004) focus primarily on the meanings that people give to their relationships and their practices of kinning and de-kinning. That is to say that there is now less interest in formal understandings of blood ties or marriage ties, and a greater emphasis on the meanings and emotions people attach to those defined as kin (or relatives or simply as close) (Finch and Mason, 1993, 2000). These meanings are created and practised in various ways through rituals, such as 
birthdays or religious celebrations, through memory work and the keeping of photos and mementoes and the telling of stories, through to practical caring and sharing (Gillis, 2004; Miller, 2001; Smart, 2007). Qualities of affection, norms of reciprocation, attentiveness to personhood and so on, all combine to create bonds which in turn can be more important than blood or genetic ties. Notwithstanding this emphasis on the quality of relationships, in a parallel world of cultural meanings, blood or genetic links do carry special meanings. This specialness should not imply that these links indicate good-quality relationships, but, even where such relationships are poor, they occupy a kind of iconic status in the cultural and personal imaginary. Both anthropological and sociological work on kinship increasingly reveal that people have complex relationships with both relatives and others defined as close or as elective kin (Weeks et al., 2001; Weston, 1997). The clichés 'Blood is thicker than water' and 'You can choose your friends but not your family' seem to be equally prevalent and now, in addition, more people refer to families of choice, often meaning a mélange of genetic kin and elective kin or friends (Spencer and Pahl, 2006). This means that it is possible to hold a range of contradictory views, often deploying different clichés in different contexts, but adhering to all of them without apparent ontological insecurity.

Returning to the points above about whether there is a clear distinction between so-called 'physical' truth and legal truth (and so whether further measures should be taken to bring them into line), it seems important to be attentive to these kinds of complexities of kinship. The problem with Eekelaar's approach is that he seems to imagine that establishing kinship is straightforward (at least now that we have DNA testing), but he seems to forget that kinship is nested in relationships which are lived and meaningful. Legal truth (founded exclusively on genetic testing) can cut through and disrupt these relationships. For Eekelaar this is not a problem because it is seen as a means of achieving power for the weakest member, namely the child. However, it is not clear that the secrets he wishes to force into daylight are simple matters of parents' power over their children. For example, the desire to keep paternity a secret may well be a way of protecting a child and not merely a way of saving face for an adult (Turney, 2005). Revealing to a husband that a child was conceived from a passing affair could mean divorce and poverty for both mother and child, so the child may live a life in the full knowledge of her paternity, but s/he may be materially impoverished as well. In exploring these issues I want to turn to an exploratory study on family secrets.

\section{Mass Observation Archive}

In 2000 Dorothy Sheridan of the Mass Observation Archive (MOB) sent out a Directive $^{4}$ to members inviting them to write on their family life. One hundred and sixty eight women and 50 men replied to this Directive, some writing 
at considerable length. One of the specific questions embedded in the broad framework of family life was on family secrets. Not all the respondents to the Directive chose to address this issue; indeed a few were offended at its inclusion. However, 85 (50 per cent) of the women and 27 ( 54 per cent) of the men said something about family secrets. The population of people who write for Mass Observation (MO) are predominantly middle-class retired professionals. Among the women who responded to this Directive the main profession was teachers, followed by clerical workers, administrators, librarians and civil servants. A number simply described themselves as housewives, but the impression given was that the majority of these also were middle-class. The typical occupations for the men respondents were similar, but also included managers and engineers of various sorts. There were some respondents from manual occupations (for men this was 16 per cent, for women it was harder to determine), but without doubt this was a skewed sample in terms of social class. In respect of age the largest group of men ( 44 per cent) were between 70 and 79 years, reflecting the fact that writing for MO appears to be something people take up when they are retired. The women were more evenly distributed, with the largest group (27 per cent) aged between 60 and 69 , and the rest more or less evenly spread in the age bands $40-49,50-59$ and $70-79$ years $(18,20$ and 21 per cent respectively). There were 'outliers' in the $30-39$ and $80-89$ age groups ( 6 per cent each) and 2 per cent in the 20-29 range.

The nature of this sample, containing as it did many engaged in amateur genealogy and many with very long personal memories and documentary evidence, allowed me to trace the ways in which family secrets appear to have changed over the decades. A note of caution is necessary here, however, because although the stories of secrets told 'fit' well with documented histories of prevalence of illegitimacy, informal adoptions, hidden pregnancies and so on (Gill, 1977; Laslett, 1977; McLaren, 1978; Sauer, 1978; Smart, 1992; Spensky, 1992), these stories are sometimes based on rather dim recollections and even on unsolved family mysteries. Some were more clearly accredited with official documents such as birth certificates, but even so the respondents to the MO Directives are engaged in constructing narratives rather than writing factual histories and so their stories should be read with this knowledge in mind (Sheridan et al., 2000). The composition of this sample of respondents might also be seen as a problem to sociological research because it is clearly not representative and is entirely voluntaristic. Yet as far as this study was concerned, this composition of predominantly middle-class writers was potentially a bonus. This is because of the cultural relationship between class position and perceived respectability. While the secrets of both middle- and working-class families might be of equal interest, there is something particularly significant in the discovery that middle-class families (and aspiring middle-class families) had many secrets that they were anxious to keep from public knowledge. If it were not for this 
archival collection, we might have few other ways of accessing the family secrets of the middle classes in the recent past. The secrets reveal how fragile respectability could and can be, but also show how cultural and social resources can be deployed to keep them from public knowledge.

It is of course also important to consider what is meant by a family secret since this is far from self-evident. This small study cannot claim to have access to all possible varieties of secret, as obviously Mass Observers would only write about the things they felt (relatively) comfortable revealing or indeed things they knew (or had found out) about. There are likely to be whole seams of secrecy that are not revealed in the Archive. But, arising from the kinds of things that Mass Observers were willing to reveal, it would seem that family secrets fall into several different categories. There were secrets about distressing illnesses or disabilities, and often mental illnesses were 'hushed up' by families. Financial irregularities or disputes over inheritances were also mentioned, but these were too rare to form any clear pattern. Secrets over homosexuality were also prevalent, but because the MO archivists asked a specific question about gays and lesbians in the family at the same time as asking about family secrets, narratives on the secrecy of sexual orientations were not spontaneous. This means that some respondents did link homosexuality with secrecy in the past (even the recent past) but many wrote about it outside the conceptual framework of secrecy. For this reason I shall not discuss responses on homosexuality here. The largest category of secrets I discovered in the MO accounts concerned reproductive secrets. These included accounts of illegitimacy, informal adoptions, premarital conceptions and secrets surrounding illicit conceptions and assisted conceptions. Of the 85 women who spoke of having secrets in their families, there were 54 accounts of this kind of secret. For the 27 men, there were 18 stories of this kind. There seems therefore to be a custom of secrecy around irregular reproductive issues and it might be possible to suggest that contemporary secrecy over assisted reproduction has its precursor in secrecy over illegitimacy, adoption and also paternity. I shall therefore attempt to map the chronology of these secrets in the MO accounts and will also seek to situate them in the legal and social (and religious) context of their times.

\section{The context of reproductive secrecy}

I suggest that there is a need to situate reproductive secrets in their historical background and that this process may lead to an understanding that openness and secrecy in families are not simply matters of individual integrity but also of social, legal and cultural context. Although personal morality is an issue here, it is problematic to insist that those who keep secrets are manipulative or disingenuous unless one also has an understanding of context. This context not only allows for an appreciation of why certain things are deemed shameful (and 
hence need to be kept secret) at certain times, but also why they lose their stigma when, for example, the law changes. But it is also possible to see how 'new' secrets become necessary as social conditions change and this, in turn, alerts us to the problem of imagining that keeping reproductive secrets is some leftover practice of a bygone age which is out of place in modern times.

In reading the family stories in the $\mathrm{MO}$ archive it is possible to discern a rough chronology of reproductive secrets, which, as I note above, fits with documented histories of illicit reproduction. Stories concerning the late nineteenth and early twentieth century were replete with accounts of illegitimacy. Thus people in their 50 and 60 s would often tell stories of grandparents who were either illegitimate, or who had a child who was illegitimate. These stories often told of the babies being raised by grandparents or other relatives who could include them easily with their existing children.

I know one of the aunts had an unexpected baby but the little one just got tacked on to the large family of another aunt. (P 425 Female, married, former nurse, aged 62)

These stories also included ones where a child might be born illegitimately and sent off to relatives or adopted formally, but where the same couple then went on to marry and have legitimate children who were therefore full sibling to the adopted child. Even in these cases, it seemed that the legitimate children might not be told of the existence of their illegitimate sibling. These accounts also often focused on 'confusions' around the dates of births, deaths and marriages. At a time when 'official' certificates were rare and when stories of their loss or accidental destruction could more or less safeguard a secret, it seems that parents sought to disguise the fact of premarital conception and sometimes premarital birth. Of course, at the beginning of the twentieth century, both premarital birth and premarital conception gave rise to the status of illegitimacy for the child, and so parents who went on to marry would have very strong motivation to hide the discrepancy over dates. Moreover, when birth certificates were available, it seems that some grandparents insisted that a child was born prematurely so as not to give away the fact of a premarital conception. In two cases in the Archive there was 'confusion' over the date, and even the fact of the death of a husband which later turned out to be a means of 'legitimating' a subsequent marriage and the children born to the couple.

The shame of having an illegitimate child weakened as the twentieth century unfolded and this is almost certainly linked to the incremental changes made to the laws on bastardy. It became possible, for example, to legitimise a child conceived or even born before marriage if the couple were both free to marry at the time of the conception. However, illegitimacy was still a dreaded status and it is clear from the MO accounts that pre-marital conceptions were a matter of great shame (and hence the tendency for shotgun weddings) throughout the first half of the twentieth century and beyond. 
The focus on illegitimacy gave way in the accounts to stories of formal adoption in the 1950 s and 1960s. These were mostly tales from adults who had discovered that they were adopted often quite late in life. The fact that adoptive parents kept the status of their children secret was entirely customary at the time. It was not regarded as a deceit but as a way of protecting the best interests of the child, and of course of preserving the respectability of the families involved. The process of recording the adoptive parents as legal parents on birth certificates also obscured the genetic parentage of formally adopted children. Moreover, in many cases of formal adoptions in the 1950s and 1960s, birth mothers were advised to forget about their illegitimate children and to return to 'normal' life where they could later marry and have proper, legitimate children (Spensky, 1992). In the MO archives there were two or three accounts from women who knew of relatives who had been sent, or who were sent themselves, to Mother and Baby Homes to have their illegitimate children in secret. Ironically, as informal adoption practices were replaced by formal procedures in the post-war decades, secrecy surrounding genetic parentage became even more impenetrable. In the MO stories of informal adoption it appears that children often found out about their 'real' parents because neighbours or other relatives knew the whole story and at some stage let it out. Equally, some MO narrators spoke of a relative who discovered they were informally adopted when requiring permission to marry under the age of 21 or on acquiring their birth certificate for the same purpose. Informal adoptions could therefore be fairly leaky secrets, while the later formal adoptions were much more unyielding in their ability to preserve secrecy.

Many of the MO narrators were telling personal stories of old family secrets which affected their forefathers, or sometimes horizontal kin, but which were stories located in a specific moment in history. Few gave the impression that they realised that their particular secret was likely to be common-place nor did many seem to appreciate why their parents or grandparents were so determined to keep certain things secret. Some wrote in a rather bemused way about why people in the past would have thought it so important to hide a pre-marital conception, perhaps little knowing about its legal and social consequences for a child.

Looking at the cases I have cited [about premarital conception], they are to do with people's perceptions at the time; about ignorance and lack of contraception; about what was considered 'correct'. (R 1227 Female, aged 56, married)

I don't know why there had to be so much secrecy, it was not a very terrible secret. (B 1665 Female, aged 66, single)

Others thought that these secrets gave character to otherwise rather shadowy figures from the past:

I have ... found a good many skeletons in the family cupboard. I have visions of my ancestors lining up when I die to give me a hard time. Though I hope what I have written about them 
helps to make them real people to their descendants rather [than] just names in a geneology (sic). (H 1543 Male, married, aged 70)

However, not all reproductive secrets were so ancient. Some secrets revealed in the Archive were current and some concerned living kin or even the narrator's own living children. These secrets could involve either the longstanding dilemma of paternity uncertainty or more contemporary dilemmas arising from new forms of assisted reproduction. Hence the following account was written by the sister of a woman who had an affair and became pregnant, but who never told her husband that the child was not his. Unfortunately she told her sister (the narrator) who had to carry the burdensome secret with her for years:

I know the truth at the time would have thrown everything up in the air, and the 'secret' was best kept for her own reasons ... but I now see it was not good to involve anyone else. (N 2058 Female, aged 56, divorced)

Another narrator wrote of her quandary over knowing about the conception of her granddaughter and yet realising that it has become, over time, a secret:

I suppose at the moment the family secret that bothers me is the fact of having an IVF granddaughter. She is now 9, learning the 'facts of life' and I think she ought to be told how her life started. There are so many different ways of conceiving and starting life that these matters are common knowledge and should be talked about openly. However, I don't think my granddaughter has been told and this could be a problem as her cousins know and might talk about it with her. So I feel I ought to raise this with my son but haven't found the right moment. It may be that her parents feel strongly that she shouldn't be told - yet it was never a secret while it was happening. (B 1533 Female, aged 74, married)

It would seem that 'old' secrets over illegitimacy, premarital conceptions and adoption have given way to 'newer' dilemmas arising from assisted reproduction. This changing pattern of secrets is, as I have noted above, clearly linked with (although not necessarily caused by) changes to the law governing these areas of family life. For example, Martin Richards (2006) has traced the complex relationships between law and paternity in England from Artificial Insemination by Donor (AID - now known as assisted insemination) to the rise of DNA testing in the late 1990s. In so doing he outlines the ways in which law and policy have dealt with reproductive 'fictions', turning those fictions which were defined as in the public interest into legal facts, while rejecting others and seeking to punish their perpetrators. Thus, for example, he quotes from the 1984 Warnock Committee Report in their recommendation that a child conceived by a woman of AID should be treated legally as the offspring of her husband, thus conferring legitimacy on the infant. The Committee stated:

We are fully aware that this can be criticised as legislating for a fiction since the husband of a woman who has conceived by AID will not be the genetic father of the child and the register of births has always been envisaged as a true genetic record. Nonetheless, it would in our view be consistent with the husband's assuming all parental rights and duties with regard to the 
child. (Richards, 2006: 57, quoting from the Report of the Committee of Inquiry into Human Fertilisation and Embryology, 1984: 26. My emphasis)

The question therefore that should perhaps be asked when confronted by reproductive secrets is why some are (or have been) condoned and even encouraged, and why some increasingly or newly invite censure and approbation. In returning to Eekelaar's proposition about the need to align 'physical' truth with legal truth, we might also ask what the consequences of this re-alignment might be. Should the sister (above) who knows her nephew is not the child of her brother-in-law now be able to invoke the law in order to tell both of them? Should the grandmother (above) above tell her grandchild or be able to use the law to force her son to tell her how she was conceived? It is important therefore to consider what absolute truth telling might mean in families when it concerns paternity and reproductive issues. In order to explore this I shall now turn to two recent studies.

\section{Paternity secrets}

In a small-scale study of paternity secrets, Turney (2005) interviewed 15 women who had experience of 'paternity uncertainty'. Typically these women were in a long-term relationship or were married, but had had affairs or 'one night stands' which meant that they could not be certain of the genetic fatherhood of their children. Turney argues that at the time of her study in Australia, women who 'deceived' their partners into believing that the children they were raising were their genetic offspring were vilified both because they were seen as passing off another man's child on an innocent partner, but also because they were depriving their child of their right to know their true parentage. However, from her interviews she discovered that the situation the women found themselves in was much more complicated than this. Many feared that their existing partner would leave them if they revealed their sexual liaison and they thought that this would be harmful for the child they were carrying. Others feared violence and so were simply too afraid to rock the boat. None wanted to find a solution through abortion since they felt that there was a strong chance that the child could be their partner's and they wanted to give birth to and raise the infant. Turney argues:

From the presented accounts, it is clear that paternity secrets are deeply held, complex, and difficult to disclose. Failing to immediately confess another, and often unimportant, distasteful or distressing sexual event, in the context of an unexpected pregnancy and a promising or permanent relationship, set these women on a trajectory from which it became increasingly difficult to exit ... The imperative to tell the truth was weighed against the harsh moral judgments that attend the moral panic about them. (2005: 243)

In other words, Turney's research reveals the extent to which the personal and social conditions under which these women were living made it very hard for 
them to tell the possible truth about the paternity of the child they were carrying. So, although the cultural context is changing (viz the trend towards scientifically based truths about paternity combined with a child's legal right to know), the social conditions under which many women are living are still incongruous with this new, stringent requirement.

\section{Maternity secrets}

In an ethnographic study with parents undergoing IVF involving egg donation, Monica Konrad (2005) has written about the moral reasoning that parents go through when considering whether to tell their children about their origins. Egg donation was seen to present quite complex issues because the recipient mothers gestated the embryos and spoke in terms of the flow of their blood in their baby's veins and the ways in which their bodies nourished and ultimately gave birth to their infants. Konrad interviewed parents who were planning to tell their children of their origins and who were keeping memory boxes for them. But equally there were those in her sample who did not plan to tell. These parents often saw no reason to 'tell' because the legal mother was the birth mother and the legal father was the genetic father. They were confident of the clinic's matching procedures and so did not fear a child being born with the wrong colour hair or eyes and so on, and so they did not fear any mismatches which would need explaining. Konrad talks of 'active not-knowing'. Active not-knowing would involve avoiding finding out about donors or asking questions which might upset a particular world view. Not thinking about half siblings is also a strategy of not-knowing. But this not-knowing, she argues, is also woven into an account which gives real substance to what is actively known, for example gestating and breast feeding a baby is seen as a vital biological process which is woven into the moral account as being of more importance than genetic ingredients. Konrad found that parents who were planning to tell their children about their genetic origins tended to be sceptical about the importance of genes, genetics and physical resemblance. These parents favoured the importance of social parenting and so were not fearful of revealing the 'truth'. However, parents who felt that biogenetic relatedness was in fact highly significant tended to be the ones who were uncomfortable with disclosure. This is perhaps not as counter-intuitive as it first appears since parents who felt that biogenetics created an intangible bond were fearful that the discovery of such relatedness would weaken their child's bond with them and thus would be the harbinger of loss.

Konrad's study is also very attentive to the problem of living with secrets or, as she would put it, active not-knowing. While active not-knowing, she argues, can keep perceived problems at bay, secrets have to be actively kept; they are not forgotten so they do not go away. Over years they may grow in significance, or circumstances may change making them more 'dangerous'. So what was a small 
secret to start with can become more burdensome and more morally unpalatable later. Yet telling the truth later is also far more damaging because it can undermine other aspects of a relationship based on trust. Thus there is a greater investment in keeping things secret the longer the secret is kept. But, as she points out, even if one intends to 'tell', there is the issue of when to tell. So, for example, should the mother with paternity doubts tell her partner immediately she finds she is pregnant, or should she wait until after the birth when she may be able to ascertain the infant's paternity with greater certainty? Or should she actively not-know? Should the birth mother of the egg-donated embryo start telling the baby with her breast milk, or should she wait until the child asks pertinent questions about procreation? If the latter, what does it mean if the child does not ask until they are 18 or even older? It does not take much imagination to realise how difficult these tasks of telling can be, even if one intends to tell.

This takes us back once again to Eekelaar's position on truth. His principles are fine ones but the question is whether law and policy should increasingly be harnessed to impose these principles (in the form of 'truth') on family relationships? More specifically, should the form of truth that is to be imposed be based on a model of scientifically derived genetic truth, which, by its elevation in this way, would become more significant than other truths (such as those arising from gestation or giving birth or those arising from active caring and love) (see Bell and Bennett, 2001). A comparison with the field of genetic testing for inherited diseases is useful here. Alison Shaw's (2006) discussion of South Asian families and genetic testing has shown that people confronted with scientific findings on inherited diseases may nonetheless feel it is unethical and inappropriate to worry their kin about a condition they may not actually develop or which may not ultimately be passed on. Hence there are intimations that people are not always willing to act in ways which accord with a specific scientific 'truth' (Marteau and Richards, 1996). People may put into the balance a concern over the feelings of others, or they may discount the advice of professionals, preferring to act according to other norms. Thus the status of scientific knowledge, and even the right to know about genetic inheritance, can be subject to codes of familial relationships which may apply very different ethical criteria (Richards, 1996). In families, secrets may be felt to be necessary for the preservation of relationships, and the 'truth' may be taken to be less important than stabilising fictions. So Shaw's study reveals that it is unwise to assume that there is an automatic adoption of genetic truth in families just because the tests on which these truths are based have empirical scientific validity. Put simply, she argues that this is not how family relationships work.

\section{Discussion}

It is difficult to predict how far the insistence on genetic truth in family law and policy might progress and how such policies may ultimately change personal and 
familial relationships. As far as genetic truth is concerned, it is clear that both family law and policy have shifted to accommodate the new trend with remarkable speed (Freeman and Richards, 2006). Adoptive parents are now encouraged to view adoption as a way of looking after someone else's child rather than as a way of acquiring their 'own' child. There is also a clear policy preference for allowing an adopted child to know about their bio-parent(s) and even to have contact if it is suitable and feasible. Equally, after divorce in most western societies there is strong encouragement for children to remain in contact with their biological fathers and, where possible, to live with both parents, thus creating a situation where the child may have sets of parents (that is, biological and 'step') in different households (Smart et al., 2001). Moreover, the old practice of adopting stepchildren on marriage (and thus legally excluding a divorced biological parent) has fallen out of favour because it is now held that maintaining contact with all biological parents is the best policy for children. Judged by these modern standards, the kinds of family stories and secrets revealed by the MO narrators may seem truly shocking, even though the practices they described would have been both common and condoned at the time. This quotation from a Mass Observer is a clear example of this:

One thing that has always fascinated me about my own and my wife's fairly recent ancestors is the level of pre-marital sex that clearly occurred, if you compare birth and marriage certificates, and the casual way children were treated. It seems to me that the early part of the century, despite the prudishness associated with it, was full of illicit relations and illegal adoptions. (P 2759 Male, aged 50, married)

It is easy therefore to interpret the gradual adoption of genetically determined reproductive truth as a story of progress away from harmful or murky practices towards a more enlightened and scientifically informed approach to relationships. However, there is another way to interpret the relationships between culturally elevated truths, secrets and forms of knowing. The need for a certain kind of secrecy at different times and in different circumstances can be interpreted as a response to social vulnerability. In this way secrets might serve as a form of protection against economic hardship, social rejection or personal denunciation. An emergent insistence on genetic truth and transparency may simply create other forms of vulnerability, especially if cultural mores and familial norms have not changed greatly. The availability of scientific certainty over such things as paternity cuts across delicate social and personal relationships, and while the secrets that a mother might wish to keep could be harmful, the truth proclaimed by a man who renounces fatherhood may be equally damaging. So alongside this potential re-alignment of relationships it is important to remember the extent to which these are also relationships of power. The drive towards genetic truth in familial relationships presumes that openness is good because it creates a level playing field of knowledge. However, family members themselves may not 
be on an equal footing and so this kind of openness may simply bring with it different forms of vulnerability. Returning to Foucault's analysis, knowledge is never outside power but rather deeply implicated in power relationships. In making this point I am not arguing that secrets are 'good things', nor that it was better when families sustained their social reputations by keeping secrets; rather I am suggesting that changing the rules about which secrets may be kept and which may not does not automatically transform relations of power between genders and generations. These new truths are simply played out on the existing social landscapes in the way that old truths were played out in their context. Moreover, the legal insistence on only one kind of truth, namely genetic, in family relationships may simply promote the claim to truth of science above other claims concerned with caring, relationality and the preservation of kinship bonds. There may be better ways of managing the complex issues that arise from messy relationships and human reproduction than through the use of legal regulation.

\section{Acknowledgements}

Mass Observation material reproduced with the kind permission of the Trustees of the Mass Observation Archive, University of Sussex.

\section{Notes}

1 For example, just go into Timesonline website and put 'family' and 'secret' into the search engine and hundreds of articles pop up. Sometimes these involve 'celebrities' but not always, which suggests that the lure of family secrets is not exclusively linked to a prior interest in the rich and famous. And see personal accounts such as that by Colin Harris in The Guardian (Family Section, 11 February 2006: 3). The article ran with this title: 'As a child Colin Harris was fond of his Uncle Bill. A close family friend, Bill bought him books and taught him Scrabble. It was only years later her realised why they had so much in common.'

2 For example, the BBC Website http://www.bbc.co.uk/history/familyhistory has a section specifically on Family Secrets which is flagged in these terms: 'Find out how to discover the skeletons and scandals in your ancestors' closets'.

3 For example, the BBC series 'Who Do You Think You Are?' which traced the family backgrounds of various celebrities actually uncovered some very painful secrets (or at least buried knowledge), causing distress and anguish in some cases. However, the general theme of the programmes was that it was a 'good thing' to know the truth about the past, no matter how painful.

4 The Mass Observation Archive is based at the University of Sussex. It is a collection of writings from the general public started in 1937 who were, originally, invited to record their daily observations of life around them. In more recent times the Archive has adopted the practice of sending out to their volunteer writers special 'Directives' which are specific questions deemed pertinent at a given moment (for example, Prince Charles' wedding) or by social researchers. The Archive is a very particular kind of data set which, until recently, was not really thought to be of value to sociological research. However, see Savage (2007) for a full discussion of the value of this special collection. 


\section{References}

Bell, D. and Bennett, B. (2001), 'Genetic secrets and the family', Medical Law Review, 9: 130-61.

Carsten, J. (2000), "Knowing where you've come from": Ruptures and continuities of time and kinship in narratives of adoption', Journal of the Royal Anthropological Institute, 6: $687-703$.

Carsten, J. (2004), After Kinship, Cambridge: Cambridge University Press.

Davidoff, L., Doolittle, M., Fink, J. and Holden, K. (1999), The Family Story: Blood, Contract and Intimacy, 1830-1960, London: Longman.

Eekelaar, J. (2006), Family Law and Personal Life, Oxford: Oxford University Press.

Finch, J. and Mason, J. (1993), Negotiating Family Responsibilities, London: Tavistock/Routledge.

Finch, J. and Mason, J. (2000), Passing On: Kinship and Inheritance in England, London: Routledge.

Fortin, J. (1994), 'Re F: “The gooseberry bush approach"', The Modern Law Review, 57: 2, 296-307.

Foucault, M. (1979), The History of Sexuality, Volume 1, London: Allen Lane.

Freeman, T. and Richards, M. (2006), 'DNA testing and kinship: paternity, genealogy and the search for the "truth" of our genetic origins', in F. Ebtehaj, B. Lindley and M. Richards (eds.), Kin Matters, Oxford: Hart Publishing.

Furedi, F. (2004), Therapy Culture: Cultivating Vulnerability in an Uncertain Age, London: Routledge.

Giddens, A. (1992), The Transformation of Intimacy, Cambridge: Polity Press.

Gill, D. (1977), Illegitimacy, Sexuality and the Status of Women, Oxford: Blackwell.

Gillis, J. (2004), 'Gathering together', in A. Etzioni and J. Bloom (eds.), We Are What We Celebrate, New York: New York University Press.

Goudsblom, J. and Mennell, S. (eds.) (1998), The Norbert Elias Reader, Oxford: Blackwell.

Hazleden, R. (2004), 'The pathology of love in contemporary relationship manuals', The Sociological Review, 52: 2, 201-17.

Jamieson, L. (1998), Intimacy: Personal Relationships in Modern Societies, Cambridge: Polity.

Jamieson, L. (1999), 'Intimacy transformed? A critical look at the "pure relationship"', Sociology, 33: 3, 477-94.

Konrad, M. (2005), Nameless Relations, Oxford: Berghahn Books.

Laslett, P. (1977), Family Life and Illicit Love in Earlier Generations, Cambridge: Cambridge University Press.

Marteau, T. and Richards, M. (eds.) (1996), The Troubled Helix, Cambridge: Cambridge University Press.

McLaren, A. (1978), Birth Control in Nineteenth Century England, London: Croom Helm.

Miller, D. (ed.) (2001), Home Possessions, Oxford: Berg.

Richards, M. (1996), 'Families, kinship and genetics', in T. Marteau and M. Richards (eds.), The Troubled Helix, Cambridge: Cambridge University Press.

Richards, M. (2006), 'Genes, genealogies and paternity: making babies in the twenty-first century', in J. R. Spencer and A. du Bois-Pedain (eds.), Freedom and Responsibility in Reproductive Choice, Oxford: Hart Publishing.

Rose, N. (1991), Governing the Soul: The Shaping of the Private Self, London: Routledge.

Sauer, R. (1978), 'Infanticide and abortion in nineteenth-century Britain', Population Studies, 32: $1,81-93$.

Savage, M. (2007), 'Changing social class identities in post-war Britain: perspectives from Mass Observation', Sociological Research Online, 12: 3, http://www.socresonline. org.uk/12/3/6.html.

Shaw, A. (2006), "The contingency of the "genetic link", in constructions of kinship and inheritance - an anthropological perspective', in J. R. Spencer and A. du Bois-Pedain (eds.), Freedom and Responsibility in Reproductive Choice, Oxford: Hart Publishing.

Sheridan, D., Street, B. and Bloome, D. (2000), Writing Ourselves: Mass-Observation and Literacy Practices, New Jersey: Hampton Press. 
Smart, C. (1992), 'Disruptive bodies and unruly sex: the regulation of reproduction and sexuality in the nineteenth century', in C. Smart (ed.), Regulating Motherhood: Historical Essays on Marriage, Motherhood and Sexuality, London: Routledge.

Smart, C. (2007), Personal Life, Cambridge: Polity.

Smart, C., Neale, B. and Wade, A. (2001), The Changing Experience of Childhood: Families and Divorce, Cambridge: Polity.

Smith, C. and Logan, J. (2004), After Adoption: Direct Contact and Relationships, London: Routledge.

Spencer, L. and Pahl, R. (2006), Rethinking Friendship: Hidden Solidarities Today, Woodstock: Princeton University Press.

Spensky, M. (1992), 'Producers of legitimacy: homes for unmarried mothers in the 1950s', in C. Smart (ed.), Regulating Motherhood: Historical Essays on Marriage, Motherhood and Sexuality, London: Routledge.

Turney, L. (2005), 'Paternity secrets: why women don't tell', Journal of Family Studies, 11: 2, $227-48$.

Warnock Committee (1984), Report of the Committee of Inquiry into Human Fertilisation and Embryology, Cmnd 9314, London: HMSO.

Weeks, J., Heaphy, B. and Donovan, C. (2001), Same Sex Intimacies: Families of Choice and Other Life Experiments, London: Routledge.

Weston, K. (1997), Families We Choose: Lesbians, Gays, Kinship, second edition, New York: Columbia University Press.

\section{CAMbridge JOURNALS}

